\section{Körperflüssigkeiten, extravasale}

\author{
A. M. Gressner ${ }^{1}$ und O. A. Gressner ${ }^{2}$ \\ ${ }^{1}$ Labor Dr. Wisplinghoff Berlin, Berlin, Deutschland \\ ${ }^{2}$ Labor Dr. Wisplinghoff Köln, Köln, Deutschland
}

\section{Synonym(e) Extravasate}

Englischer Begriff non-vascular body fluids; extra-vascular body fluids

Definition Außerhalb des Blutgefäßsystems befindliche physiologische oder pathologische Flüssigkeitsansammlungen spezifischer chemischer und/oder morphologischer $\mathrm{Zu}$ sammensetzung und (patho-)physiologischer Funktionen.

Beschreibung Pathologische Flüssigkeitsansammlungen in präformierten Körperhöhlen (Aszites, Perikarderguss, Pleuraerguss, Zystenflüssigkeit) sind ein wichtiges labormedizinisches Untersuchungsgut für die ätiologische (differenzialdiagnostische) Abklärung mit folgenden Kriterien:

- Nicht entzündlich-entzündlich mit Bestimmung von Gesamtprotein ( $\triangleright$ Protein, gesamt im Urin; \ Protein, gesamt im Serum (Plasma)) und Leukozyten

- Benigne-maligne mit Bestimmung von Tumormarkern ( $\vee$ Tumormarker) und ggf. Tumorzellen

- Nicht infektiös-infektiös mit Erregeridentifizierung
- Ggf. Beimengungen von Blut, Gallenflüssigkeit, Liquor cerebrospinalis und anderen Körperflüssigkeiten

Physiologische extravasale Flüssigkeiten sind $>$ Urin, \ Liquor cerebrospinalis, Gallenflüssigkeit ( $\downarrow$ Galle), \ Magensaft, Duodenal- und Pankreassaft, Fruchtwasser, Nasensekret, Schweiß ( $\vee$ Schweißanalytik), Speichel ( $\vee$ Speichelgewinnung), $\checkmark$ Seminalflüssigkeit (Sperma) und Synovialflüssigkeit ( $>$ Synovia-Analyse).

Eine Identifizierung extravasaler Körperflüssigkeiten kann mit einigen typischen Kenngrößen vorgenommen werden: Fruchtwasser (Fetoprotein), Duodenal- und Pankreassaft (hohe Amylase-, Lipase-, Chymotrypsinaktivitäten), Magensaft ( $\mathrm{pH}=1-2)$, Urin (hohe Kreatininkonzentration), Speichel (hohe Speichelamylaseaktivität, Kalium ca. $20 \mathrm{mmol} / \mathrm{L}$, Natrium ca. $30 \mathrm{mmol} / \mathrm{L}$ ), Schweiß (Chlorid ca. $30 \mathrm{mmol} / \mathrm{L}$ ), Sperma (hohe saure Phosphataseaktivität, mikroskopischer Spermiennachweis), Liquor ( $\beta$-2-Transferrin), Synovialflüssigkeit (hohe Viskosität, Hyaluronan, ggf. Kristalle). Bei allen genannten Analytbestimmungen in den extravasalen Körperflüssigkeiten ist eine Parallelbestimmung im Serum erforderlich, um typische Analytgradienten festzustellen.

\section{Literatur}

Greiling H, Gressner AM (1995) Lehrbuch der Klinischen Chemie und Pathobiochemie, 3. Aufl. Schattauer-Verlag, Stuttgart

Thomas L (2005) Labor und Diagnose, 6. Aufl. TH-Books Verlagsgesellschaft mbH, Frankfurt am Main 